JURNAL ILMIAH KEBIDANAN IMELDA

Vol.7, No.1, Maret 2021, pp. 6-11

ISSN: 2597-7180 (Online), 2442-8116 (Print)

http://jurnal.uimedan.ac.id/index.php/JURNALKEBIDANAN

\title{
GAMBARAN PENGETAHUAN IBU TENTANG PEMBERIAN IMUNISASI POLIO PADA BALITA DI RUMAH SAKIT IMELDA PEKERJA INDONESIA (IPI) MEDAN
}

\author{
Mira Indrayani \\ Universitas Imelda Medan, Indonesia
}

\begin{tabular}{l}
\hline Article Info \\
\hline Article history: \\
Received Mar 08, 2021 \\
Revised Mar 13, 2021 \\
Accepted Mar 15, 2021 \\
\hline
\end{tabular}

\section{Keywords:}

Knowledge

Mother

Polio Immunization

\begin{abstract}
Polio immunization is an immunization that aims to prevent poliomyelitis. Poliomyelitis is a disease of the central nervous system caused by one of the three related viruses 1, 2, and 3. Immunization is the most important factor in eradicating polio. Purpose Immunization provides immunity to infants to prevent infant disease and death caused by common diseases. This type of research is descriptive. The sampling technique used is non-probability sampling. The number of samples collected in the study amounted to 45 mothers who had children under five at the Indonesian Worker Imelda Hospital (IPI) Medan. The measurement technique for each variable is to ask 21 questions for the knowledge variable using the Guttman scale in the form of a closed questionnaire, then formulated using the range (class) formula and the stugers formula to determine the criteria for respondent's answer and to find out the score and percentage. From the results of the study, it was found that the majority of mothers' knowledge about polio vaccination was quite sufficient as many as 22 respondents (49\%) and a minority of good knowledge as many as 8 respondents $(18 \%)$. For this reason, it is still very important to educate mothers with toddlers about polio vaccination at the Indonesian Workers Imelda Hospital (IPI) Medan.
\end{abstract}

This is an open access article under the CC BY-SAlicense.

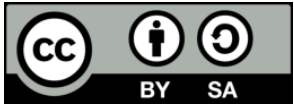

\section{Corresponding Author:}

Mira Indrayani,

Program Studi S1 Kebidanan,

Universitas Imelda Medan,

Jl. Bilal No. 52 Kelurahan Pulo Brayan Darat I Kecamatan Medan Timur, Medan - Sumatera Utara.

Email: miraindrayani19@gmail.com

\section{INTRODUCTION}

Polio merupakan imunisasi yang bertujuan mencegah penyakit poliomyelitis. Pemberian vaksin polio dapat dikombinasikan dengan vaksin Difteri, Pertusis dan Tetanus (DPT). Poliomyelitis adalah penyakit sistem saraf pusat yang disebabkan oleh salah satu dari tiga virus terkait, virus polio type 1, 2 dan 3. Struktur virus ini sangat sederhana hanya terdiri dari ribonucleic acid (RNA) genom dalam sebuah caspid tanpa pembungkus. Ada 3 macam serotype pada virus ini yaitu type 1(PV1), type 2 (PV2) dan type 3(PV3), Ketiganya sama-sama bisa menginfeksi tubuh dengan gejala yang sama (Mulyani dan Rinawati, 2013).

Menurut survei yang dilakukan Organisasi Kesehatan Dunia (WHO) dan Kementrian Kesehatan Indonesia, virus polio liar di Indonesia pada tahun 2005 berasal dari Sudan atau Nigeria yang berada di Arab Saudi. Virus menyebar ke negara lain melalui jamaah, jemaah dan pekerja lainnya (Widoyono, 2009).

Pada tahun 2002 dan 2003 Organisasi Kesehatan Dunia (WHO) tidak lagi melaporkan virus polio, terdeteksi 1 kasus pada Juli 2004, 31 kasus terdeteksi pada Agustus dan jumlahnya terus meningkat menjadi 126 pada akhir tahun 2004. Sekarang, itu telah menjadi negara yang populer akhir-akhir ini. Pada 6 November 2004, seorang gadis dari jemaah Haji lumpuh akibat virus polio di Jedah. Pada tanggal 15 
Desember 2004, seorang anak Nigeria berusia 5 tahun lumpuh di kampung pengungsian ilegal dekat kota Mekkah (Widoyono, 2005).

Pada tahun 2005, kasus polio pertama kali muncul di Cidahu, Suka-bumi, Jawa Timur, Jawa Tengah dan Lampung. Berdasarkan Data terakhir terdapat total 295 kasus polio di 10 provinsi dan 22 kota di Indonesia (Widoyono, 2005). Kasus Polio di Sumatera Utara telah ditemukan kasus polio sebanyak 302 kasus positif polio liar yang menyebar pada 40 kabupaten dan kota di 10 Provinsi termasuk Sumatera Utara (Sumut). Di Sumut, data yang ada menunjukkan terjadi 10 kasus. Asisten III Bidang pembinaan Hukum dan Sosial Setdaprov Sumut Sofyan Nasution menyebutkan, ke 10 kasus positif polio liar itu, menyebar pada tujuh daerah. Yakni tiga kasus di Kabupaten Karo, dua kasus di kota Medan dan selebihnya satu kasus, yakni Deli Serdang kabupaten Serdang Bedagai, Asahan, Samosir dan Labuhan Batu. Menurut Sof yan, masalah ini menjadi catatan tersendiri untuk segera diatasi. Sebab itu Semua Pihak harus mendukung upaya pemberantasannya melalui gerakan imunisasi nasional melalui Imunisasi Nasional di North Carolina (PIN). Keberhasilan Pekan Imunisasi Nasional (PIN) tahun 2006 di daerah sangat tergantung pada peranan pemerintah daerah. Oleh karena itu, demi menyongsong hari depan anak Indonesia yang berkualitas. Khususnya pada Sumut, sangat diharapkan kepada semua pihak, khususnya jajaran Pemerintah daerah untuk mensukseskan Imunisasi Nasional di North Carolina (PIN) 2006 di wilayah masing-masing (Sofyan, 2008).

Virus polio termasuk dalam kelompok entero virus, famili picornaviriade. Dikenal tiga macam serotipe virus polio yaitu P1, P2 dan P3. Virus polio ini menjadi tidak aktif apabila terkena panas, formaldehid, klorin dan sinar ultraviolet. Virus polio sangat menular, pada kontak antar rumah tangga (yang belum diimunisasi) derajat serokonvensi capai lebih dari $90 \%$. Kasus poliomielitis sangat menular sebelum dan 7 hingga 10 hari setelah timbulnya gejala, tetapi Virus polio dapat ditemukan di tinja dalam waktu 3 hingga 6 minggu (Satgas, 2008).

Masa inkubasi polio biasanya 7- 14 hari dengan kisaran 3 sampai 35 hari. Manusia adalah satusatunya reservior dan sumber penularan. Virus ditularkan antar-manusia melalui rute-fekal. Ketika kondisi kebersihan dan sanitasi yang baik tidak memungkinkan penularan feses melalui mulut, penularan melalui sekresi faring dapat terjadi. Makanan yang terkontaminasi dan bahan lain dapat menyebarkan virus, meskipun ini jarang terjadi. Pada akhir masa inkubasi dan timbulnya gejala, penderita polio sangat mudah terinfeksi. Virus poliomielitis dapat ditemukan di sekret tenggorokan setelah 36 jam, hingga 1 minggu dan dalam tinja 72 jam hingga 3-6 minggu atau lebih. Sebab virus polio dapat menyerang orang dari segala usia dengan tingkat kelumpuhan hanya sekitar 1\% akan mengalami kelumpuhan pada bayi lebih kecil dari pada orang dewasa (Widoyono, 2009).

Polio dapat menyebabkan gejala yang biasa atau penyakit yang sangat parah. Polio menyebabkan demam, muntah - muntah dan tegang otot dan dapat juga terkontaminasi pada saraf-saraf, mengakibatkan kelumpuhan permanen, penyakit ini dapat melumpuhkan otot pernapasan dan otot yang mendukung proses penelanan, menyebabkan kematian. Dua hingga lima persen pasien polio akan meninggal karena penyakit tersebut, dan sekitar 50\% pasien yang selamat akan menderita kelumpuhan seumur hidup. Jika kotoran pasien mencemari makanan, air atau tangan, polio dapat menular (Proverawati dan Andhini, 2010).

Pengobatan pada penderita polio tidak spesifik. Tujuan pengobatan adalah untuk meredakan gejala dan mendukung pengobatan untuk meningkatkan daya tahan tubuh pasien. Layanan terapi fisik diperlukan untuk meminimalkan kelumpuhan dan mencegah terjadinya atrofi otot. Orang dengan kelumpuhan yang terus menerus dapat menggunakan perawatan ortopedi. Pengendalian penyakit yang paling efektif adalah pencegahan melalui vaksinasi dan paralisis flaksid akut (AFP). (Widoyono, 2009).

Pada tahun 1998, Majelis Kesehatan Dunia (WHA) membentuk dunia bebas polio pada tahun 2005, tahapannya sebagai berikut: (1) harapan untuk menghentikan penyebaran virus polio liar pada tahun 2000; (2) harapan untuk membentuk organisasi regional asia tenggara pada tahun 2004 (SEARO). SEARO adalah sistem divisi regional WHO yang mencakup Asia Tenggara. Apabila resolusi ini berjalan sesuai rencana WHO beserta negara-negara diseluruh dunia akan menghentikan imunisasi polio pada tahun 2010 seperti halnya keberhasilan umat manusia membasmi virus cacar. Pada umumnya tidak terdapat efek Samping. Efek samping berupa paralisis yang disebabkan oleh Vaksin sangat jarang terjadi. Pemberian vaksinasi polio tidak boleh dilakukan pada orang yang menderita defisiensi imun. Tidak ada efek yang berbahaya yang ditimbulkan akibat pemberiam polio pada anak yang sedang sakit, namun jika ada keraguan misalnya menderita diare maka dosis ulangan dapat diberikan setelah sembuh (Mulyani dan Rinawati, 2013).

Dari survei awal yang penulis lakukan di Rumah Sakit Imelda Pekerja Indonesia (IPI) Medan terdapat beberapa ibu yang belum mengerti tentang manfaat imunisasi polio, maka dari uraian di atas peneliti tertarik untuk melakukan penelitian "Gambaran pengetahuan ibu tentang vaksinasi polio pada balita di Rumah Sakit Imelda Pekerja Indonesia (IPI) Medan tahun 2019.

Berdasarkan uraian diatas maka perumusan masalah dalam penelitian ini adalah Bagaimanakah Gambaran Pengetahuan Ibu Tentang Imunisasi Polio pada Balita Di Rumah Sakit Imelda Pekerja Indonesia 
(IPI) Medan. Penelitian ini bertujuan untuk mengetahui Gambaran engetahuan Ibu tentang Imunisasi Polio pada Balita Di Rumah Sakit Imelda Pekerja Indonesia (IPI) Medan tahun 2019.

\section{RESEARCH METHOD}

Penelitian dalam studi ini menggunakan metode penelitian deskriptif yang bertujuan untuk membuat Gambaran pengetahuan Ibu Tentang Imunisasi polio Pada Balita Rumah Sakit Imelda Pekerja Indonesia (IPI) Medan pada tahun 2019 dengan menggunakan pendekatan Cross-sectional yaitu melakukan penelitian dalam sekali waktu secara bersamaan. Metode penelitian yang digunakan ialah deskriptif untuk memecahkan dan menerangkan masalah yang sedang dihadapi pada situasi sekarang. Pengumpulan datapada penelitian ini meliputi, klasifikasi, pengolahan, membuat kesimpulan dan laporan (Setiadi, 2007).

Waktu Penelitian ini dilaksanakan pada bulan Februari-April tahun 2019. Tempat Penelitian dilakukan di Rumah Sakit Imelda Pekerja Indonesia (IPI) Medan. Populasi adalah keseluruhan objek yang akan di teliti (Setiadi, 2007). Populasi dalam penelitian ini adalah semua ibu yang mempunyai balita di Rumah Sakit Imelda Pekerja Indonesia (IPI) Medan yang berjumlah 93 Balita.

Metode sampling yang digunakan yang digunakan pada penelitian ini adalah non probability sampling. Sample adalah sebabagian dari keseluruhan objek yang akan diteliti dan dianggap mewakili seluruh atau sebahagian populasi dengan jumlah 45 responden. Teknik pengukuran yang dilakukan peneliti dengan kuesioner tertutup kepada responden sebanyak 18 pertanyaan dan diformulasikan interval jawaban variabel menggunakan rumus Sturgers untuk menentukan kriteria jawaban responden:

$$
I=\frac{\mathrm{R}}{\mathrm{K}}=\frac{\text { Skor maximal-Skor Minimal }}{\text { Kelas }}
$$

\section{Keterangan :}

$\mathrm{I}=$ Interval kelas

$\mathrm{R}=$ Jarak kelas (Skor Maksimal-Skor Minimal)

$\mathrm{K}=$ Jumlah (Kategori) (Sudjana, 2009).

Sedangkan untuk mengetahui presentase jawaban responden dengan kriteria responden, menggunakan rumus:

$\mathrm{P}=\frac{\mathrm{F}}{\mathrm{N}} \times 100 \%$

Keterangan :

$\mathrm{P}=$ persentase

$\mathrm{F}=$ Jumlah Jawaban Benar

N = Jumlah Soal (Setiadi, 2007)

Pada variabel pengetahuan dengan menggunakan skala Guttman apabila jawaban responden salah bernilai 0 dan apabila jawaban responden benar bernilai 1 sehingga kriteria jawaban responden dapat disimpulkan melalui skor dan presentase jawaban sebagai berikut:

$I=\frac{\mathrm{R}}{\mathrm{K}}=\frac{\text { Skor maximal-Skor Minimal }}{\text { Kelas }}=\frac{18-0}{3}=6$

Keterangan:

I $\quad=$ Interval

$\mathrm{K} \quad=$ Jumlah (kategori)

Range $=$ Skor maksimal - skor minimal

Sedangkan untuk mengetahui presentase jawaban sesuai dengan kriteria responden memakai rumus Determinan oleh (Setiadi, 2007) yaitu:

$\mathrm{P}=\frac{\mathrm{F}}{\mathrm{N}} \times 100 \%$

Keterangan:

$\mathrm{P}=$ perensentase

$\mathrm{F}=$ jumlah jawaban yang benar

$\mathrm{N}=$ jumlah soal 
Tabel 1. Interval Jawaban Kategori Pengetahuan

\begin{tabular}{clcc}
\hline No & Kategori Pengetahuan & Skore Jawaban & Persentase (\%) \\
\hline $\mathbf{1}$ & Baik & $13-18$ & $78-100$ \\
\hline $\mathbf{2}$ & Cukup & $7-12$ & $39-67$ \\
\hline $\mathbf{3}$ & Buruk & $0-6$ & $0-33$ \\
\hline
\end{tabular}

\section{RESULTS AND ANALYSIS}

\subsection{Hasil}

Setelah dilakukan penelitian terhadap 45 responden dengan judul "Gambaran Pengetahuan Ibu Tentang Vaksinasi Polio di Rumah Sakit Imelda Pekerja Indonesia (IPI) Medan”. Maka hasilnya disajikan pada tabel distribusi berikut ini:

\section{Data Umum}

Tabel 2. Distribusi Karakteristik Responden Berdasarkan Kelompok Umur Tentang Vaksinasi Polio Di

\begin{tabular}{llcc}
\multicolumn{4}{l}{ Rumah Sakit Imelda Pekerja Indonesia (IPI) Medan } \\
\hline No & Umur & Jumlah & Presentase (\%) \\
\hline 1 & $20-25$ tahun & 13 & 29 \\
\hline 2 & $26-30$ tahun & 20 & 45 \\
\hline 3 & $31-35$ tahun & 12 & 26 \\
\hline & Jumlah & $\mathbf{4 5}$ & $\mathbf{1 0 0}$
\end{tabular}

Dari tabel diatas disimpulkan bahwa mayoritas responden pada kelompok usia 26-30 tahun berjumlah 20 orang (45\%), usia 20-25 tahun berjumlah 13 orang (29\%) dan minoritas kelompok usia 31-35 tahun berjumlah 12 orang $(26 \%)$.

Tabel 3. Distribusi Karakteristik Responden Berdasarkan Pendidikan Tentang Imunisasi Di Rumah Sakit Imelda Pekerja Indonesia (IPI) Medan

\begin{tabular}{clcc}
\hline No & Pendidikan & Jumlah & Presentase (\%) \\
\hline 1 & SD & 14 & 31 \\
\hline 2 & SMP & 20 & 45 \\
\hline 3 & SMA & 8 & 18 \\
\hline 4 & D - III & 3 & 6 \\
\hline & Jumlah & $\mathbf{4 5}$ & $\mathbf{1 0 0}$ \\
\hline
\end{tabular}

Dari tabel diatas diketahui bahwa mayoritas pendidikan responden yaitu berpendidikan SMP berjumlah 20 (45\%), berpendidikan SD berjumlah 14 (31\%), berpendidikan SMA sebanyak $8(18 \%)$ dan minoritas pendidikan D-III berjumlah $3(6 \%)$.

Tabel 4. Distribusi Karakteristik Responden Berdasarkan Sumber Informasi Tentang Vaksinasi Polio Di Rumah Sakit Imelda Pekerja Indonesia (IPI) Medan

\begin{tabular}{clcc}
\hline No & Sumber informasi & Jumlah & Presentase (\%) \\
\hline 1 & TenagaKesehatan & 10 & 22 \\
\hline 2 & Keluarga & 19 & 42 \\
\hline 3 & Media Massa & 8 & 18 \\
\hline 4 & Media Elektronik & 8 & 18 \\
\hline & Jumlah & $\mathbf{4 5}$ & $\mathbf{1 0 0}$ \\
\hline
\end{tabular}

Dari tabel diatas dapat dilihat bahwa mayoritas responden mendapatkan informasi mengenai pemberian imunisasi polio pada balita melalui keluarga sebanyak 19 Responden (42\%), tenaga kesehatan sebanyak 10 responden $(22 \%)$ dan minoritas melalui media masa berjumlah 8 responden (18\%) dan media elektronik berjumlah 8 responden (18\%).

Tabel 5. Distribusi Karakteristik Responden Berdasarkan Sumber Pekerjaan Di Rumah Sakit Imelda Pekerja Indonesia (IPI) Medan

\begin{tabular}{cccc}
\hline No & Sumber informasi & Jumlah & Presentase (\%) \\
\hline 1 & IRT & 10 & 22 \\
\hline 2 & Petani & 25 & 56 \\
\hline 3 & Pedagang & 8 & 18 \\
\hline 4 & PNS & 2 & 4 \\
\hline & Jumlah & $\mathbf{4 5}$ & $\mathbf{1 0 0}$ \\
\hline
\end{tabular}


Dari tabel diatas dapat diketahui bahwa pekerjaan responden mayoritas petani berjumlah 25 responden (56\%), Ibu Rumah Tangga (IRT) berjumlah 10 responden (22\%), pedagang berjumlah 8 responden $(18 \%)$ dan minoritas PNS berjumlah 2 responden $(4,4 \%)$.

\section{Data Khusus}

Tabel 6. Distribusi Responden Berdasarkan Pengetahuan Tentang Imunisasi Polio Pada Balita Di Rumah Sakit Imelda Pekerja Indonesia (IPI) Medan

\begin{tabular}{clcc}
\hline No & Pengetahuan & Jumlah & Presentase (\%) \\
\hline 1 & Baik & 8 & 18 \\
\hline 2 & Cukup & 22 & 49 \\
\hline 3 & Kurang & 15 & 33 \\
\hline & Jumlah & $\mathbf{4 5}$ & $\mathbf{1 0 0}$ \\
\hline
\end{tabular}

Dari tabel diatas diketahui bahwa kebanyakan responden berpengetahuan cukup sebanyak 22 (49\%), pengetahuan kurang sebanyak 15 responden (33\%) dan sekurangnya berpengetahuan baik sebanyak 8 responden $(18 \%)$.

\subsection{Pembahasan}

\section{Distribusi Responden Berdasarkan Pengetahuan Ibu Dalam Pemberian Imunisasi Polio Pada Balita Di} Rumah Sakit Imelda Pekerja Indonesia (IPI) Medan

Mayoritas responden berpengetahuan cukup tentang imunisasi polio padabalita sebanyak 22 responden $(49 \%)$, pengetahuan kurang tentang imunisasi polio pada balita berjumlah 15 responden $(33 \%)$, pengetahuan baik mengenai imunisasi polio pada balita berjumlah 8 (18\%). Dilihat dari hasil analisis dapat disimpulkan bahwa mayoritas ibu sudah memiliki pengetahuan cukup tentang pemberian imunisasi polio pada balita tetapi berdasarkan hasil penelitian masih ditemukan ibuyang kurang memahami tentang imunisasi polio pada balita dan bagaimana cara pemberian vaksinasi polio pada balita, penyebab rendahnya pengetahuan ibu tentang imunisasi polio di Rumah Sakit Imelda Pekerja Indonesia (IPI) Medan oleh karena Ibu tidak berusaha mencari informasi tentang bahaya tidak diberikan imunisasi polio pada balita melalui media informasi seperti media massa atau melalui petugas kesehatan, bahkan sebagian ibu tidak pernah membawa imunisasi polio pada balita yang seharusnya diberikan $4 \mathrm{kali}$

Pengetahuan dapat diperoleh dari pengalaman langsung atau pun melalui pengalaman orang lain. Peningkatan pengetahuan dapat dilakukan melalui konseling individu dan konseling kelompok untuk meningkatkan pengetahuan kesehatan sehingga dapat meningkatkan perilaku individu, keluarga dan masyarakat dalam mencapai kesehatan yang optimal. Pengukuran pengetahuan dapat dilakukan melalui wawancara atau survey kuesioner. Wawancara atau angket mensyaratkan materi yang akan dipelajari ditanyakan darim objek penelitian atau orang yang disurvei kepada pengetahuan yang ingin diketahui (Notoatmodjo, 2010).

\section{CONCLUSION}

Dari hasil penelitian diatas dengan judul Gambaran pengetahuan Ibu Tentang Imunisasi Polio Pada Balita dapat disimpulkan: Mayoritas Ibu sudah memiliki pengetahuan yang cukup tentang imunisasi polio pada balita dan berdasarkan hasil penelitian masih ditemukan ibu yang kurang memahami tentang imunisasi polio pada balita dan bagaimana cara pemberian imunisasi polio pada balita, penyebabnya adalah rendahnya pengetahuan ibu tentang vaksinasi polio pada balita di Rumah Sakit Imelda Pekerja Indonesia (IPI) Medan oleh karena Ibu tidak berusaha mencari informasi tentang bahaya tidak diberikannya imunisasi polio pada balita pada masa sekarang bisa melalui media informasi seperti media massa atau melalui petugas kesehatan, bahkan sebagian ibu tidak pernah membawa balitanya untuk di imunisasi.

\section{REFERENCES}

Effendy. 2004. Dasar-dasar Kepewatan Kesehatan Masyarakat. Jakarta: EGC.

Fitriani, Sinta. 2011. Promosi Kesehatan. Jakarta: Graha ILmu.

Ismanto. 2011. Pengertian Ibu dan Balita yang Sehat. http://ismantosurya.blogspot.com. Di unduh pada tanggal, 29 April 2019.

Mubarak. 2010. Pengetahuan Dalam Pelayanan Kesehatan. Jakarta: Rineka Cipta.

Mulyani, Rinawati. 2013. Imunisasi Untuk Anak. Yogyakarta: Nuha Medika.

Notoatmodjo, Soekidjo. 2007. Promosi Kesehatan dan Ilmu Perilaku Kesehatan. Jakarta: Rineka Cipta.

Notoatmodjo, Soekidjo. 2010. Ilmu Pendidikan dan Perilaku Manusia. Jakarta: Rineka Cipta.

Proverawati, Andhini. 2010. Imunisasi dan Vaksinasi. Jakarta: Nuha Medika.

Rudy. 2010. Defenisi Sikap. http :// berbagaireferensi.blogspot.com. Diunduh Pada Tanggal, 12 April 2016. 
Satgas. 2008. Pedoman Imunisasi Di Indonesia. Jakarta: Badan Penerbit Ikatan Dokter Anak Indonesia. Scribd. 2010. Tentang Ibu dan Balita. http://id.scribd. com/doc/208535708/ ibu dan balita diakses pada tanggal, 22 Feb 2016.

Setiadi. 2007. Konsep \& Penulisan Riset Keperawatan. Yogyakarta: Graha Ilmu.

Soetjiningsih. 2009. Tumbuh Kembang Anak. Jakarta: EGC.

Sofyan, Mustika. 2006. 50 Tahun IBI: Bidan Menyongsong Masa Depan. Jakarta: Ikatan Bidan Indonesia.

Widoyono. 2005. Penyakit Tropis, Epidemiologi, Pencegahan dan Pemberantasannya. Jakarta: Erlangga.

\section{BIOGRAPHIES OF AUTHORS}

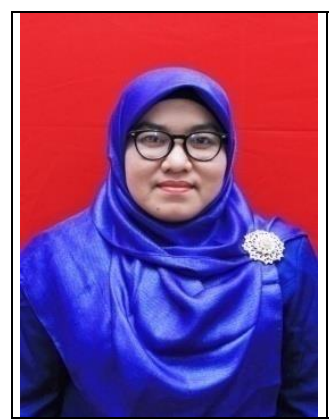

Mira Indrayani, Gelar D-III diperoleh dari Akademi Kebidanan Imelda Medan, Jurusan Kebidanan pada tahun 2007. Gelar D4 diperoleh dari Poltekes Kemenkes RI Medan, Jurusan Bidan Pendidik Tahun 2009. Magister Kesehatan diperoleh dari Universitas Sumatera Utara, Jurusan Kesehatan Reproduksi pada tahun 2018. Saat ini aktif sebagai dosen tetap di Prodi S1 Kebidanan Universitas Imelda Medan dan menjabat sebagai wakil Rektor 3 .

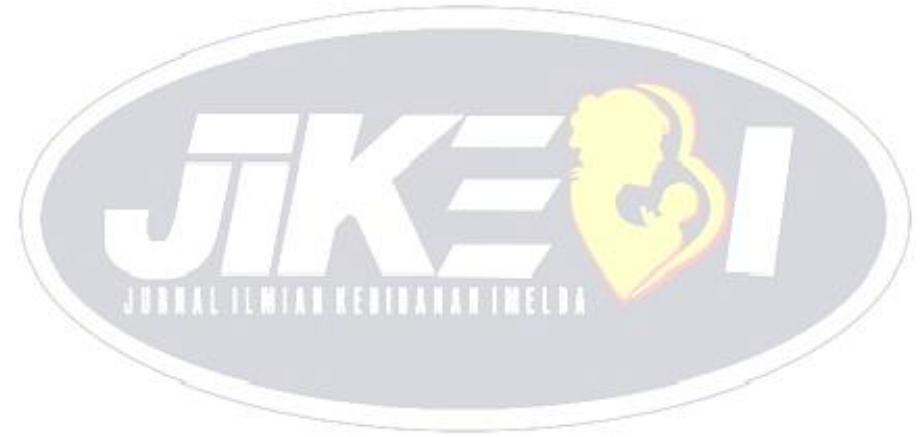

